\title{
Engagement Levels in a Graphic Design Clicker Class: Students' Perceptions around Attention, Participation and Peer Learning
}

\author{
Daniela Gachago, Amanda Morris, and Edwine Simon \\ Cape Peninsula University of Technology, \\ Cape Town, South Africa
}

\section{gachagod@cput.ac.za morrisa@cput.ac.za simone@cput.ac.za}

\section{Executive Summary}

Research into the uses of personal response systems or 'clickers' shows that their use increases students' engagement levels in the classroom. In South Africa, clicker usage is still in its infancy, with little research published in the field. This study reports on 37 Graphic Design students' perceptions of the use of clickers and their engagement levels (attention, participation, and active class discussion) in small clicker classes.

Clickers were introduced in three interventions in the third term of the 2010 academic year in an attempt to improve students' participation in class discussions. The devices were used for individual and peer voting. Peer and class discussion either preceded or followed the voting process. The study employed a mixed method research design. Data was collected through open-ended student questionnaires, clicker questions during classes, and one focus group discussion.

Drawing on cooperative learning theory, this paper discusses student engagement on three levels. Firstly, clickers seize students' attention through the simplicity, novelty factor, and fun element they bring to class. Secondly, they encourage student participation through the anonymity they offer, which is especially important when the language of learning and teaching is not the students' first language.

Thirdly and most importantly, clickers encourage peer discussion. Students reported that by being confronted with opposing points of views, which lead to uncertainty or conceptual conflicts, they were propelled to re-conceptualise their own arguments, which then in turn led to more refined and thoughtful conclusions. This resonates with the central tenet of Johnson, Johnson, and Smith's Controversy Theory (1998), which advocates the benefits of cooperative student learning. Students reported that peer discussions improved their confidence to participate in the class discussions.

The studio-based approach in design education aims to mimic the 'real world' design studio and,

Material published as part of this publication, either on-line or in print, is copyrighted by the Informing Science Institute. Permission to make digital or paper copy of part or all of these works for personal or classroom use is granted without fee provided that the copies are not made or distributed for profit or commercial advantage AND that copies 1) bear this notice in full and 2) give the full citation on the first page. It is permissible to abstract these works so long as credit is given. To copy in all other cases or to republish or to post on a server or to redistribute to lists requires specific permission and payment of a fee. Contact Publisher@InformingScience.org to request redistribution permission. therefore, also the collaborative design processes followed in the real world studio. As an additional finding in this study, we suggest, that peer voting, the process of voting in pairs, although not always comfortable, can promote the skill of collaborative decision-making. This skill is particularly important for future graphic designers, whose work 
will rely considerably on successful collaboration with their team members.

More research is needed to validate students' perceptions of their levels of engagement with their actual engagement level in clicker classes. It is suggested that other disciplines and study levels be included in future research projects.

Keywords: clickers, personal response systems, student engagement, peer learning, class participation, cooperative learning, graphic design

\section{Introduction}

Addressing the historical educational inequalities of access to and throughput in Higher Education amongst different races is a government policy goal since the political transition in 1994 in South Africa. However, no significant increase in the actual participation of black African students in Higher Education has been achieved so far (Council on Higher Education, 2007). Furthermore, student performance continues to be racially differentiated with black students (consisting of black African, coloured, and Indian students) doing worse than white students in most disciplinary fields and black African students performing worst of all (Council on Higher Education, 2007). This problem is complex and multilayered and shaped by many issues.

One of the suggestions to overcome these challenges is the introduction of Extended Curriculum Programmes (ECPs). Foundational provision enables students from disadvantaged educational backgrounds to "build sound academic foundations for succeeding in their programme of choice" (Council on Higher Education, 2007, p. 43) and is thus "aimed at facilitating equity of access and of outcomes" (Department of Education (DoE) as cited in Council on Higher Education, 2007, p. 43). Under-preparedness of students associated with disadvantaged educational backgrounds often involves a number of factors, such as conceptual development, academic language proficiency, and approaches to learning, as well as subject knowledge. Efficient foundation programmes recognise and build on capabilities of students and are designed to cater for students' diverse experiences and educational needs (Council on Higher Education, 2007).

The ECP at the University involved in this study was set up in 2007 by extending the first year of study by one year, allowing for more intensive teaching of smaller groups of students. Extending teaching time allows lecturers to use more active learning interventions in their teaching, such as project-based learning, group work, or practical investigations (Garraway, 2009). Although the intention of the ECP is to increase throughput and access, a common problem is that students pass the programme with the benefit of assistance and often struggle on entering the mainstream where there is less support (Kloot, Case, \& Marshall, 2008).

One way of increasing students' academic success in Higher Education is to focus on student engagement; there is wide consensus in the literature that student engagement is the single best predictor of a student's learning and personal development (Astin, 1984; 1987; 1999; Kuh, 2009).

Two of the indicators of student engagement, in addition to taking initiative, self-motivation, and independent experimentation, are spontaneous collaboration and peer coaching amongst students (Sandholtz, Ringstaff, \& Dwyer, 1994).

Electronic voting systems (EVS), also called personal response systems (PRS) or 'clickers' have entered the United States and United Kingdom Higher Education system as a tool to enhance students' participation and engagement (Draper \& Brown, 2004; Draper, Cargill, \& Cutts, 2002;

Kay \& LeSage, 2009; Simpson \& Oliver, 2007). A distinct research stream in the literature around clickers focuses on the use of clickers to encourage student collaboration and peer learning (Crouch \& Mazur, 2001; Mazur, 1997).

In South Africa clickers' usage is still in its infancy. The institution where this study was carried out invested in 100 clickers at the end of 2009, primarily for ECP students. The extended nature 
of ECP courses, which allows lecturers more time to develop interactive approaches to teaching and learning, was seen as a good testing ground for clickers. A main challenge in the ECP Graphic Design course, the focus of this study, is the lack of student engagement in class discussions. To counteract the fear of lecturing staff, that "students' push of a button may have replaced opportunities for thinking aloud and practising verbal communications skills in the class settings" (Patterson, Kilpatrick, \& Woebkenberg, 2010, p. 606), our particular interest in this study was to facilitate active dialogue amongst students. Our study explores students' perceptions of the potential of clickers to enhance their engagement, on three levels:

1. attracting students' attention,

2. improving participation and

3. promoting class discussion.

Cooperative learning theory, especially Johnson, Johnson, and Smith's Controversy Theory (1998) was employed to explore clickers' potential to facilitate peer learning amongst students. A mixed method research design was followed, comparing written student feedback and class and focus group discussions with quantitative clicker question results. As main conclusion, this study will show that in small classes clickers are best seen as a tool to encourage collaboration and peer learning. This is particularly important for future graphic designers, who will find themselves, in industry, working in teams and relying on collaborative decision-making processes.

\section{Benefits of Clickers}

Clickers are small handheld devices which allow students to answer multiple choice questions in class in an anonymous way, allowing the immediate display of results (see Figure 1). The use of clickers offers many benefits (Kay \& LeSage, 2009):

- overall improved attitudes of students,

- classroom environment benefits, such as improved students' attendance, attention, participation, and engagement,

- learning benefits, such as improved interaction, discussion and peer learning, contingent teaching, improved learning performance, and quality of learning, and

- assessment benefits, such as improved feedback, the potential for formative assessment, and the possibility of comparing responses with other students.

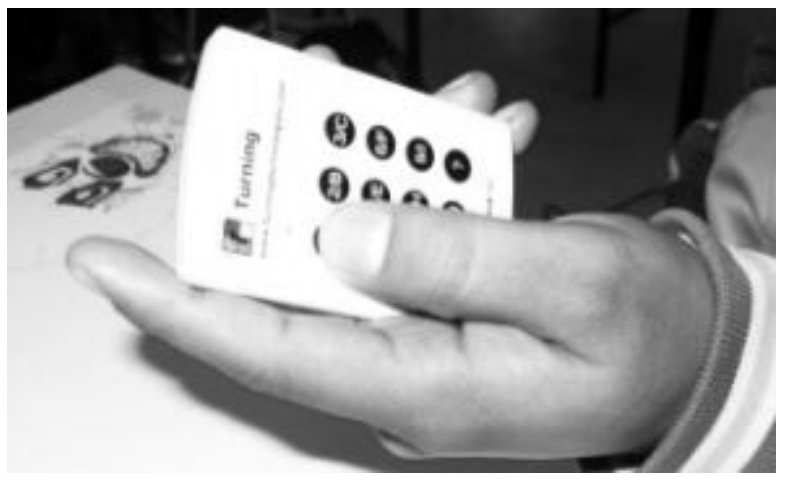

Figure 1: Student holding clicker

While most research on clickers focuses on their potential to improve teaching in large classrooms and "very little attention has been paid to the impact of clickers in small classes" (Walker \& Barwell, 2009, p.3 ), our study was set in the context of a small class in a practical subject, with ample space for feedback from lecturers to students. Some of the benefits listed above, such as improving class attendance, fostering knowledge acquisition, or enhancing feedback from lec- 
turers to students, are therefore of less relevance to us. Our main interest in this study centres on students' perceptions of clickers as a tool to improve their attention and participation in class. Furthermore we are interested in their perceptions of clickers as a tool for enhancing class discussion.

\section{Students' Perceptions of Clickers}

Students are generally positive about the use of clickers in teaching and learning (Caldwell, 2007; Fies \& Marshall, 2006; Hu, Bertok, Hamilton, White, Duff, \& Cutts, 2006; Preszler, Dawe, Shuster, \& Shuster, 2007; Simpson \& Oliver, 2007). Studies show that students in lower level courses especially had more positive overall impressions than students in upper-division courses (Preszler et al., 2007) and had fewer problems accepting the changes associated with introducing clickers in the classroom (Trees \& Jackson, 2007). Students in general report that the technology is easy to learn and to use (Kay \& LeSage, 2009).

\section{Clickers and Student Attention}

Research shows that students' attention span lasts no longer than 15 to 20 minutes (D'Inverno, Davis, \& White, 2003). Interspersing lectures with carefully designed clicker questions can refocus students' attention at crucial moments. Numerous studies have reported that students' attention can benefit from the use of clickers (Caldwell, 2007; Draper \& Brown, 2004; D'Inverno et al., 2003).

\section{Clickers and Students' Participation}

There is substantial evidence in studies to show that using clickers increases student participation when compared to lectures where clickers are not used (Kay \& LeSage, 2009). The anonymity that clickers offer, the possibility of students voting without being judged by their lecturer or their peers, combined with the feedback clickers give to students and staff alike - all these seem to improve student participation (Patterson et al., 2010). They offer students an opportunity to participate in class without "fear of ridicule, should they volunteer an incorrect response" (Banks, 2006, p. vii). This is particularly important for second language learners, who often struggle to participate in class because of cultural factors inhibiting active participation, such as lack of competency in the language of instruction (Stagg \& Lane, 2010).

\section{Clickers and Student Engagement}

Studies looking at student engagement focus on students' perceptions of their own engagement during clicker classes (Kay \& LeSage, 2009). Findings are mainly based on quantitative student surveys. These studies link student engagement to students' improved attention and focus through clickers, improved attendance, enjoyment, and fun experienced in clicker lectures (Addison, Wright, \& Milner, 2009; Preszler et al., 2007; Stagg \& Lane, 2010; Trees \& Jackson, 2007). However, there is little focus on the reasons why students are more engaged in these lessons and whether their engagement leads to learning (Fies \& Marshall, 2006; Kay \& LeSage, 2009).

Qualitative elements in studies are predominantly limited to analysing open-ended questions in students' surveys (Graham, Tripp, Seawright, \& Joekel, 2007; Kyei-Blankson, 2009; Patry, 2009). Few studies employ focus group discussions with students about clickers and student engagement. Paterson et al.'s qualitative study (2010) reports that clickers supported increased engagement and interaction in the classroom, which brought the class closer. They stress the importance of assessing lecturers' teaching practices with respect to activities that enhance student engagement and exploring students' own perceptions towards activities that they believe engaging. Walker and Barwell's study (2009), one of the few studies that focused on the impact of clickers 
in small classes, reported that clickers encourage class engagement through their functionality, novelty, and anonymity. Confirming Banks' (2006) findings, they conclude that, in smaller classes, clickers' main benefit lies in "collaborative learning [amongst students] rather than the knowledge transfer from teacher to learner" (Walker \& Barwell, 2009, p. 45).

\section{Critiques around the Use of Clickers and Student Engagement}

More critical voices warn against using clickers without carefully planning appropriate pedagogical approaches. van Dijk, van den Beer, and van Keulen (2001) emphasise the need to distinguish between student activity and cognitive experiences. They argue that "interactive teaching will not automatically result in students who are more activated compared with students in traditional lectures" (p. 25). Students may simply participate in the voting process for the sake of it, without thinking deeply about questions the lecturer is asking.

\section{Clickers and Peer Learning}

Literature around clickers and improved student learning focuses on the need to engage students in dialogue with the lecturer and with each other. Laurillard's conversational framework (2002) is mentioned in various papers, with its underlying assumption that learning results from the process of ongoing and adaptive dialogue between teacher and learners. Mazur (1997) is one of the main proponents of using clickers for peer learning, which can help students who normally struggle to improve their examination results. The 'Mazur sequence' suggests that students should be allowed to vote individually at first and then, after showing first results, discuss these with their classmates and vote again. Only after this step does the lecturer summarise and explain results. Crouch and Mazur show in their longitudinal study (2001) that using the 'Mazur sequence', combining individual clicker voting with peer discussion (which is critical to the success of peer learning) resulted in substantially increasing the number of students giving correct responses to conceptual questions and in improving student engagement in class discussion.

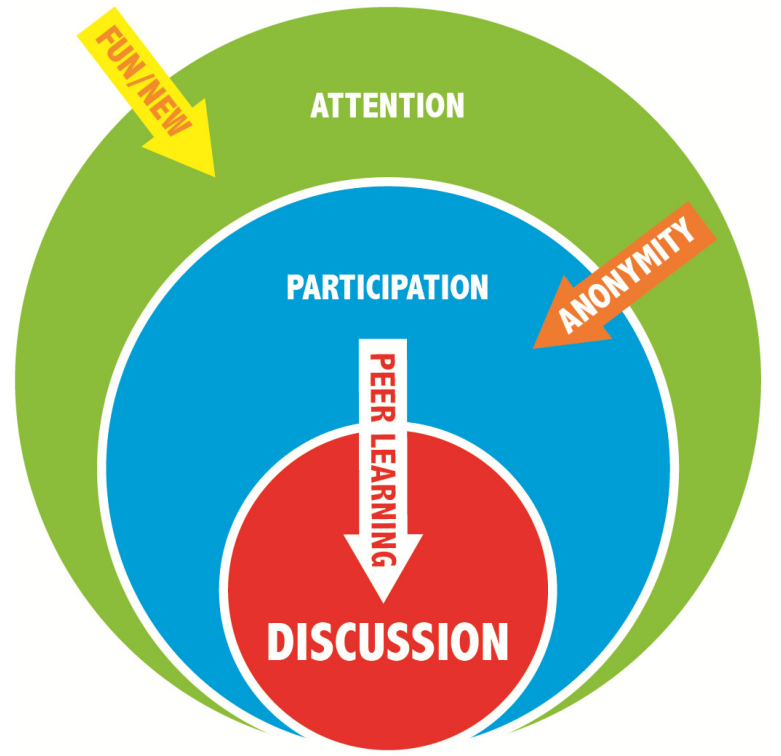

Figure 2: Engagement level of students in the ECP graphic design clicker lecture (although in the literature the terms 'participation' and 'engagement' are used separately, and often interchangeably, we see participation as one level of engagement).

Based on the literature review, we see student engagement in our clicker lectures on three levels, as illustrated in Figure 2. On the lowest level, clickers seize students' attention by offering nov- 
elty and fun; on the second level clickers increase students' participation through the anonymity they offer; on the highest level, clickers improve active class discussion through peer learning.

\section{Cooperative Learning Theory}

Cooperative learning theory was employed for this study to explore clickers' affordances to facilitate peer learning amongst students. Peer learning is not well defined in the literature and is often used interchangeably with words such as collaboration, cooperation or tutoring. Foot, Morgan, and Shute (1990) differentiate between three main approaches to peer-to-peer learning, namely, peer tutoring (teaching between peers), peer collaboration, and cooperative learning. Collaboration and cooperation are differentiated by their degree of organisation. While cooperative learning is associated with well-structured knowledge domains and division of labour amongst students (Slavin \& Cooper, 1999), collaborative learning emphasises "natural learning" (Johnson et al., 1998, p. 28) and involves the "mutual engagement of participants in a coordinated effort to solve the problem together" (Roschelle \& Teasley, as cited by Resta \& Laferriere, 2007, p. 66).

Literature links collaborative and cooperative learning to enhanced student engagement (Astin, 1987) and student engagement with learning: high levels of involvement prove to be an independent predictor of learning gain (Astin, 1984; Endo \& Harpel, 1982). Tinto (1997), for example, shows that collaborative learning activities allow for the development of peer support networks, which encourage class attendance and participation. Collaborative learning also leads to improved quality of learning, deeper and richer, where students not "only learn more ... but better" (Tinto, 1997, p. 614).

Johnson et al. (1998) base the impact of cooperative learning on cognitive development theories, which view cooperation as an essential pre-requisite for cognitive growth. Their controversy theory posits that students need to be confronted with opposing points of views, leading to uncertainty or conceptual conflicts, for students to re-conceptualise and look for more information, which then in turn leads to more refined and thoughtful conclusions: "The key steps for the student are to organise what is known into a position; to advocate that position to someone who advocates an opposing position; to attempt to refute the opposing position while rebutting attacks on one's own; to reverse perspectives so that the issue is seen from both points of view simultaneously; and, finally, to create synthesis to which all sides can agree" (p. 30).

Johnson et al. (1998) differentiate between three interrelated ways of cooperative learning: formal cooperative learning, informal cooperative learning, and cooperative base groups. These three groups are defined mainly by the degree of organisation and duration of students working together. For our study, the term "informal cooperative learning" is most suitable, "typically temporally and ad hoc, formed for a brief period of time (such as intermittent two- to four-minute discussions during a class session)" (p. 37). They suggest that one way of using informal cooperative learning groups is to give students time to turn to a classmate nearby to discuss briefly a question posed by the lecturer, in order to focus student attention and ensure students' cognitive processing of the discussed material.

Johnson et al.'s (1998) work is based on Vygotsky's theory of learning (1978), which promotes collaborative work with more capable peers and instructors for cognitive development and intellectual growth. Vygotsky suggests two levels of development when discussing student learning. The "actual development level" (p. 85) is defined by the student's abilities when working as an individual and solving a problem in isolation. The zone in which a learner's intelligence levels is measured by his ability to perform tasks through mediation, understood as the assistance or guidance by a more skilled peer or teacher, is the "potential development level" (p. 86). The "zone of proximal development" (p. 84) exists between the actual and potential development level. The 
idea of learning being for and foremost social by requiring mediation through communicative interaction in this zone of proximal development is the focus of Vygotsky's theory of learning.

\section{Context for the Study and Process of Investigation}

\section{Context}

The 2010 ECP Graphic Design class consisted of 39 students. These students were an average of 19 to 20 years old; the majority were male. Students came from disadvantaged communities and schools and entered the ECP course via referral, because they were academically underprepared for first year mainstream tertiary education.

In general, the approach to design education is largely practical and studio-based, helping students develop design-based problem-solving skills by creating artefacts on their own under the facilitation of a lecturer. The studio-based approach in design education encourages collaborative learning through discussion and critical feedback sessions. Studio teaching aims to mimic the 'real world' design studio and, therefore, also the collaborative design processes followed in the real world studio. In the world of work, a group of creative people come together to solve a client's design problem. This collaborative effort ensures that the final solution to a design problem is one that has been developed by exploring all the possible solution avenues and that the client gets the best possible solution to the problem. It is therefore essential that students start to foster this collaborative decision-making skill at the early stages of their designer careers.

However, because of these students' academic history of mainly teacher-centred instruction, the majority of students expect to 'be taught' as opposed to the constructionist notion of a design classroom (Papert \& Harel, 1991), especially in more theoretical subjects such as History of Art. When rated on general class participation by their lecturers on a scale from 1-3 (1 being low participation to 3 being high participation), more than half of the student body of this study were rated on a low participation level (see Table 1).

Table 1: General class participation of students rated by lecturing staff

\begin{tabular}{|l|c|c|}
\hline Participation level & N & \% \\
\hline low participation & 22 & $57 \%$ \\
\hline average participation & 10 & $26 \%$ \\
\hline high participation & 7 & $18 \%$ \\
\hline Total & $\mathbf{3 9}$ & $\mathbf{1 0 0 \%}$ \\
\hline
\end{tabular}

\section{Interventions}

The research team in this study consisted of three Graphic Design lecturers: one the coordinator of the ECP Graphic Design programme and two members of the institution's Centre for Higher Education Development (CHED).

Three clicker interventions were designed and implemented over the course of two months in terms three and four of the academic year. Placing the interventions towards the end of the 2010 academic year meant that students were already settled in their roles as students and had a grasp of the discipline. The clicker questions were mainly non-factual questions (without a right or wrong answer) and were meant to lead students into a class discussion. Clicker voting was either preceded or followed by peer and/or class discussion.

Session one was an academic literacy class, run by the CHED academic literacy lecturer. In this session the lecturer read a poem about the 2010 Soccer World Cup and used clickers to engage 
students in a discussion around the impact of the World Cup on South Africa in general and, more specifically, on the students as Graphic Design professionals. The focus of this session was on written communication. The lecturer phrased her questions to emphasise the importance of reading Graphic Design briefs in a detailed manner. Students were given a clicker each and voted first individually, which then led to a class discussion. Students were asked to provide written feedback on the clicker session at the end of the class, in line with the focus on written communication.

Session two was run by the History of Art lecturer, who used clickers to help students reflect on a practical assignment they had been involved in and to link the experiences gained during that assignment with theoretical concepts learnt over the course of the year. Focus here was on visual communication. Clickers were handed out to pairs of students and clicker questions led to class discussions, preceded or ended by students discussing and voting in pairs. Students' feedback on the session was collected at the end of the class, using clickers.

Session three was an evaluation session on students' perceptions of using clickers. This session was run by the second CHED lecturer, who works in the Educational Technology Unit. It was structured around a sequence of clicker questions, which students answered individually, followed by a class discussion.

\section{Data Collection}

This study employed a mixed method research design, combining qualitative and, to a limited extent, quantitative data. Data was collected during the three sessions and consisted of written student feedback, clicker questions, a class discussion, and focus group discussion (see Table 2). Examples of the questions asked can be found in the Appendix.

Table 2: Methods of data collection

\begin{tabular}{|l|l|c|l|}
\hline \multicolumn{1}{|c|}{ Method } & \multicolumn{1}{|c|}{ Time } & $\begin{array}{c}\text { Number of respon- } \\
\text { dents }\end{array}$ & Type of data \\
\hline $\begin{array}{l}\text { Written student feed- } \\
\text { back (open ended } \\
\text { questionnaire) }\end{array}$ & $\begin{array}{l}\text { After session 1 } \\
\text { (5 questions) }\end{array}$ & 28 & Qualitative \\
\hline $\begin{array}{l}\text { Clicker feedback } \\
\text { questions }\end{array}$ & $\begin{array}{l}\text { After session 2 } \\
\text { (5 questions) and during } \\
\text { session 3 (14 questions) }\end{array}$ & $\begin{array}{l}\text { Number of answers } \\
\text { varied by question, } \\
\text { on average 25 }\end{array}$ & Quantitative \\
\hline Class discussion & During session 3 & 29 & Qualitative \\
\hline Focus group discussion & After session 3 & 6 & Qualitative \\
\hline
\end{tabular}

In total, 37 of the students attended at least one of the clicker interventions (there is no compulsory class attendance in the ECP Graphic Design programme, although a class attendance register is taken in most of the classes). These 37 make up the sample of this study. Average student attendance in the three interventions was 29 students.

The first intervention ended with a written questionnaire on students' perceptions of clickers, which comprised four open-ended questions. Students handed in their answers at the end of the class. The four questions focused on the benefits and challenges of using clickers as a learning tool in a Graphic Design class. This was the first time clickers had been used in a Graphic Design classroom, and students did not have the opportunity to discuss benefits or challenges of clickers with their peers before completing the questionnaire.

After sessions two and three, students were asked questions about the way clickers had been used in the previous sessions. The questions asked in session three were based on an initial analysis of 
the written feedback students gave us after session one, to verify some of the emerging themes. We used four-level Likert-scale questions (strongly agree, agree, disagree, strongly disagree). Findings were reported under two categories: agree and disagree.

In both clicker voting sessions, clickers were distributed randomly and students were assured that their responses were anonymous. The clicker software recorded the number of student votes and responses and was used to generate reports on students' answers.

During the last session, students were also encouraged to participate in a class discussion around the posed questions. After the third clicker session, six students took part in a focus group discussion (30 minutes) to revisit the issues that had emerged from their written feedback and the class

discussion. Three students were volunteers and three were selected because their written feedback represented a spread of emerging themes. In session three, the discussion around clickers and the focus group was facilitated by the non-teaching member of the research team, one of the CHED lecturers. Students' comments were recorded and transcribed to be used anonymously as prescribed by the institutional research policy.

\section{Data Analysis}

Data analysis was conducted on an on-going basis, which allowed us to explore emerging themes and pursue them in more depth in the third intervention and especially in the focus group discussion. We analysed the qualitative questionnaires and focus group data using analytical induction strategy, which involves scanning the data for categories of phenomena or themes and for relationships between such themes. Working typologies and hypotheses were developed, by examining the initial data and then modifying and refining typologies and hypotheses on the basis of subsequent data (Robinson, 1951; Znaniecki, 1934). Direct quotes were used where necessary, to capture students' intended meaning as fairly and accurately as possible. While our methods for analysing our qualitative data were inductive, we were also guided by theoretical interests and our reading of related literature (Hull, Kenney, Marple, \& Forman-Schneider, 2006).

\section{Findings and Discussion}

This section discusses findings from the qualitative data, such as written feedback and class and focus group discussions, triangulated, where possible, with the quantitative data acquired through the clicker voting sessions.

We will report findings along the three levels of our student engagement model:

1. Students' general attitudes towards clickers to improve their attention, linked in our model to simplicity, novelty, and fun,

2. Students' perceptions towards clickers as a tool to promote participation, and

3. Students' perceptions towards clickers as a tool to encourage active discussion and peer learning.

\section{Clickers and Student Attention}

Echoing general findings in the literature (Caldwell, 2007; Kay \& Lesage, 2009), our students' responses in the written student questionnaires were predominantly positive towards using clickers. The majority of students enjoyed the clicker sessions, felt involved, and looked forward to using them again. The following statements depict the general attitude of students towards clickers:

I enjoyed myself during the clicker class.

People get kind of involved in the process. 
No one left the class bored or tired [but] happy and comfortable.

After the questions were all done, I wanted more!

Looking into more detail at the reasons students enjoyed the sessions, we could identify elements of simplicity, novelty, and entertainment.

Fourteen students appreciated the simplicity and efficiency of the tool (50\%):

We just click and it's so simple.

There is less distraction and more discussion.

You learn at a faster pace and get through topics faster.

Thirteen students mentioned the novelty of clickers (46\%), and six students highlighted the fun element that clickers bring into their learning $(21 \%)$.

Clickers make the discussion more fun.

It is full of energy.

The combination of these elements helped seize students' attention and keep their focus in class, as the following quotations show:

I find it to be very innovative, exciting and it grabs my attention.

You have to refresh your mind and think about what you are going to answer ... it keeps

our minds think [ing] all the time.

These results are backed up by the clicker voting session, where $76 \%$ of students reported that they enjoyed the clicker sessions.

\section{Clickers and Student Participation}

Clickers help to create a safe, non-threatening class environment (Banks, 2006). In the written feedback eight students (29\%) spoke positively about the anonymity clickers offered. In the focus group discussion, students talked about their fear of being judged by their peers when volunteering to speak out in class. Corresponding to other findings in the literature (Simpson \& Oliver, 2007) the anonymity that clickers offer decreased this fear:

Staying anonymous [is good]: people are unsure of their answers or they're too embarrassed to say their answers or they're scared that some people might think of them differently, if they say something wrong.

Students emphasised the fact that, by using clickers, they felt that they were part of the class discussion, without being forced to speak out in class:

You will feel like you have said something because you voted ... you know the answer as to why you wouldn't agree or disagree but you don't feel like saying it in such a way that people will understand it.

Exploring this theme further in the focus group discussion, students reported that, as predominantly second-language students, they experienced major problems with English, the language of instruction at this institution. This comment depicts the problems students faced in class:

You can agree with something whether [or not] you have a reason ... you do agree in your heart, but you don't have a reason, but when someone can say ... feel free to talk with your own language ... then you can have a reason. Because you're not that perfect in English. That's why you feel so scared. But I have a reason in isiXhosa [one of the main African languages spoken in the Western Cape], but I don't know how to say it in English. 
Using clickers gave students the feeling of participation in the classroom, without being judged or ridiculed due to their lack of competency in the language of instruction, as Stagg and Lane (2010) report. In the clicker voting sessions, approximately three quarters of the students felt more active in a clicker class and appreciated the anonymity clickers offer (see Table 3).

Table 3: Student feedback in clicker voting session

\begin{tabular}{|l|c|c|c|}
\hline & I agree & $\begin{array}{c}\text { I don't } \\
\text { agree }\end{array}$ & $\begin{array}{c}\text { Total } \\
\text { \% }\end{array}$ \\
\hline Clickers help me be more active in class. & $71 \%$ & $29 \%$ & 100 \\
\hline I like it that clicker answers are anonymous. & $77 \%$ & $23 \%$ & 100 \\
\hline $\begin{array}{l}\text { Every student is active in class when we use } \\
\text { clickers. }\end{array}$ & $58 \%$ & $42 \%$ & 100 \\
\hline
\end{tabular}

Interestingly, students were divided about class participation as a whole, with only $58 \%$ of students agreeing that every student was active in class when clickers were used (see Table 3 ). This might be explained by some students' critiques on the anonymity clickers afford. In the written feedback, the main concern raised by students (six students, 21\%) was the opportunity for their peers to 'hide behind' their anonymous answers. They felt that it led to students not taking the discussion seriously or not giving honest answers:

You might get dishonest answers because it is anonymous ... other people just answer the questions without thinking clearly or don't care.

This was also an issue in the focus group, where some students argued that, because they were all still learning to speak out in class, voting should not have been anonymous - all students should acknowledge their opinions and explain why they agreed or disagreed with a certain issue. During clicker sessions, students seemed to be reluctant to explain why they disagreed with a certain point, especially if they were in the minority, as this student pointed out:

You will hardly find someone said I disagree because of A, B and $C$.

This echoes Walker and Barwell's findings (2009), that the anonymity clickers offer can come at the expense of more open and direct discussion in class.

\section{Clickers and Peer Learning}

The dominant theme in the written student feedback (20 student responses, $71 \%$ ) was the potential for clickers to encourage peer learning. Students appreciated the fact that they saw how the whole class answered - contrary to traditional class discussions, which were dominated by a few vocal students. The following student statement shows this:

It is exciting because I get to see what the response from the class is and what the majority of the class thinks.

The class discussions following clicker voting helped students refine and re-assess their own opinions:

You hear other people's opinions and then you can weigh it up with your own ... and with that you can formulate a better answer.

You hear different explanations from other people about the things that you don't even know about.

The more people speak out their ideas, the more I think on adding to what they have said. 
The opportunity for peer learning through clickers emerged strongly in the clicker voting session, with nearly all students agreeing that they enjoyed sharing opinions and learning from each other, as shown in Table 4.

Table 4: Student feedback in clicker voting session

\begin{tabular}{|l|c|c|c|}
\hline & I agree & $\begin{array}{c}\text { I don't } \\
\text { agree }\end{array}$ & $\begin{array}{c}\text { Total } \\
\%\end{array}$ \\
\hline I like to see what others are thinking. & $90 \%$ & $10 \%$ & 100 \\
\hline Clickers help us learn from each other. & $88 \%$ & $12 \%$ & 100 \\
\hline
\end{tabular}

Again, this topic was discussed during the focus group discussion. Students reaffirmed the opportunity for peer learning that clicker interventions offered them. Through arguing their case and listening to their peers, they were exposed to different views, which helped them refine and present their own argument:

I become afraid when I [am] the first person who will say something. I have to first hear some opinions and then I come up with my own opinion after that ... You can hear what other people are thinking, what they are saying and now you can take that and put it in your answer and you can provide it to the class.

Their comments relate to Crouch and Mazur's findings (2001), that students are more willing to discuss their responses when once committed (through voting). Furthermore, combining individual clicker voting with peer and class discussion seems to encourage more students to share their opinions in an open class discussion.

Echoing Tinto's findings (1997), students tended to explore specific topics on a deeper level and saw it as an opportunity for independent research;

When you speak about it, something else comes up and you go deeper into it ...

Clickers help you gain more information ... it makes you do more research about a topic, to broaden it, know more ...

When we go out of this class, we end up going to the computer, searching for more information, after using clickers.

These comments show elements of informal cooperative learning, as defined by Johnson et al. (1998) and resonate with their Controversy Theory, which postulates that by engaging with peers, individual students refine and re-conceptualise their own conclusion and, in some cases, are propelled to look for more information outside class.

Critical student feedback around peer learning focuses on the necessity for students to be voting in pairs, especially for questions without a right or wrong answer. Some students reported that compromising on an answer was not always satisfactory and left them with a feeling of frustration. The clicker voting session confirmed this: $80 \%$ of students indicated that they would prefer to have one clicker to themselves. However, being forced to reach a compromise in a peer voting situation teaches students the importance of collaborative decision-making, a critical skill for future graphic designers.

Another interesting finding refers to students' judgement of their classmates' opinions as opposed to those of their lecturers. In their first year of studies students are not yet used to critically evaluating lecturers' opinions and appreciated their peers' explanations of topics, as this student's comment shows: 
When you get information from a lecturer ... you've got to take it because it's a lecturer's opinion, but your students, they are like different people with different opinions, so it's always interesting ...

These findings confirm that the importance of peer learning and collaboration is particularly high for Graphic Design students. The nature of art and design can lead to a surface approach to learning, as the assessment focus is often on quality of an artefact rather than on the learning process of a student (Davies, 1996). Students in this study mention how they do not as yet critically assess lecturers' opinions, but rely on the lecturers' judgment as opposed to developing their own skills to assess concepts such as creativity. Peer learning can guide them towards more critical thinking about their own and their peers' work.

\section{Conclusion}

Clickers have proved their usefulness for enhancing interactivity and participation in large classes. However, there is less evidence for the use of clickers to enhance student engagement in small classes (Walker \& Barwell, 2009). This study set out to investigate students' perceptions on the use of clickers in a small Graphic Design ECP course to improve their attention, participation, and active class discussions. The findings of this study confirm the levels of students' engagement introduced in the literature review: clickers can capture students' attention through the simplicity, the novelty factor, and the fun element they bring to class; they improve participation in students through the anonymity they offer, especially important for students whose language of instruction is not their first language.

A lecturer's teaching practices and facilitation skills are crucial in promoting a class discussion which is focused, non-threatening, and efficient. However, in this study we found that what students saw as the main contribution of clickers was the facilitation of peer learning, which in turn helped them join the class discussions. These findings strengthen our view, that collaborative learning, rather than knowledge transfer from teacher to student, should be emphasised in small clicker classes. Even if the process of collaborative decision-making necessitated through peervoting is not always a comfortable experience for students, the development of this skill is crucial for future graphic designers.

This is the first time clickers had been evaluated in a learning intervention at this institution. Further research will be needed to validate students' perceptions of their own engagement levels with their actual engagement in class. Only by analysing engagement patterns through, for example, video analysis of the interventions, will we be able to confidently say that clickers encourage wider student participation on a higher level of engagement. We suggest that research be conducted in other disciplines and student bodies to expand the findings of this study.

\section{Acknowledgements}

The researchers would like to acknowledge the Graphic Design ECP lecturing team and all those students involved, for their contribution to this research. Thank you also to the ECP coordinator for offering support for attending a writing retreat, during which this paper was started.

\section{References}

Addison, S., Wright, A., \& Milner, R. (2009). Using clickers to improve student engagement and performance in an introductory biochemistry class. Biochemistry and Molecular Biology Education, 37(2), 84 91. Wiley Online Library. Retrieved from http://onlinelibrary.wiley.com/doi/10.1002/bmb.20264/full

Astin, A. (1984). Student involvement: A development theory for higher education. Journal of College Student Personnel, 25, 297-308. 
Astin, A. (1987). Achieving educational excellence. San Francisco: Jossey-Bass.

Astin, A. (1999). Student involvement: A developmental theory for higher education. Journal of College Student Development, 40(5), 518-529. Retrieved from http://www.middlesex.mass.edu/TutoringServices/AstinInvolvement.pdf

Banks, D. A. (2006). Preface. In D. A. Banks (Ed.), Audience response systems in higher education: Applications and cases (pp. vii-xv). Hershey PA: Idea Group Inc.

Caldwell, J. E. (2007). Clickers in the large classroom: Current research and best-practice tips. CBE-Life Sciences Education, 6(1), 9-20. Retrieved from http://www.lifescied.org/cgi/content/abstract/6/1/9

Council on Higher Education. (2007). Higher Education Monitor No. 6: A case for improving teaching and learning in South African higher education. Council on Higher Education. Retrieved from http://www.che.ac.za/documents/d000155/HE_Monitor_6_ITLS_Oct2007.pdf

Crouch, C. H., \& Mazur, E. (2001). Peer instruction: Ten years of experience and results. American Journal of Physics, 69, 970-977.

Davies, A. (1996). Assessment and transferable skills in art and design. International Journal of Art \& Design Education, 3, 327-331.

Draper, S., \& Brown, M. I. (2004). Increasing interactivity in lectures using an electronic voting system. Journal of Computer Assisted Learning, 20(2), 81-94. Retrieved from http://onlinelibrary.wiley.com/doi/10.1111/j.1365-2729.2004.00074.x/pdf

Draper, S., Cargill, J., \& Cutts, Q. (2002). Electronically enhanced classroom interaction. Australasian Journal of Educational Technology, 18(1), 13-23. Retrieved from http://www.dcs.gla.ac.uk/ quintin/papers/AJET2002.pdf

D’Inverno, R., Davis, H., \& White, S. (2003). Using a personal response system for promoting student interaction. Teaching Mathematics and its Applications, 22(4), 163-169.

Endo, J. J., \& Harpel, R. L. (1982). The effect of student-faculty interaction on students' educational outcomes. Research in Higher Education, 16, 115-135.

Fies, C., \& Marshall, J. (2006). Classroom response systems: A review of the literature. Journal of Science Education and Technology, 15(1), 101-109.

Foot, H., Morgan, J., \& Shute, R. (1990). Children's helping relationships: An overview. In H. Foot, J. Morgan, \& R. Shute (Eds.), Children helping children. Sussex: Wiley and sons.

Garraway, J. (2009). Success of foundation (extended programmes) in Engineering and Sciences at CPUT. In Success stories in foundation/extended programmes, 52-54. HELTASA. Retrieved from http://www0.sun.ac.za/heltasa/file.php/1/Foundation/Final_Book.pdf

Graham, C. R., Tripp, T. R., Seawright, L., \& Joekel, G. (2007). Empowering or compelling reluctant participators using audience response systems. Active Learning in Higher Education, 8, 233-258. Retrieved from http://alh.sagepub.com/content/8/3/233.abstract

Hu, J., Bertok, P., Hamilton, M., White, G., Duff, A., \& Cutts, Q. (2006). Wireless interactive teaching. In D. A. Banks (Ed.), Audience response systems in higher education: Applications and case (pp. 209221). Hershey PA: Idea Group Inc.

Hull, G. A., Kenney, N. L., Marple, S., \& Forman-Schneider, A. (2006). Many versions of masculine, 1-44. Retrieved from http://www.uclinks.org/reference/research/Hulletal.Masculinitypaper.pdf

Johnson, D. W., Johnson, R. T., \& Smith, K. A. (1998). Cooperative learning returns to college: What evidence is there that it works? Change, 27-35.

Kay, R. H., \& LeSage, A. (2009). Examining the benefits and challenges of using audience response systems: A review of the literature. Computers \& Education, 53, 819-827. 
Kloot, B., Case, J., \& Marshall, D. (2008). A critical review of the educational philosophies underpinning Science and Engineering foundation programmes. South African Journal for Higher Education (SAJHE), 22(4), 799-816.

Kuh, G. D. (2009). The national survey of student engagement: Conceptual and empirical foundations. New Directions for Institutional Research, 141, 5-20. Retrieved from http://onlinelibrary.wiley.com/doi/10.1002/ir.283/pdf

Kyei-Blankson, L. (2009). Enhancing student learning in a graduate research and statistics course with clickers. EDUCAUSE Quartely, 32(4). Retrieved from http://www.educause.edu/EDUCAUSE+Quarterly/EDUCAUSEQuarterlyMagazineVolum/Enhancing StudentLearninginaGra/192963

Laurillard, D. (2002). Rethinking university teaching: A conversational framework for the effective use of learning technologies (2nd ed.). London: Routledge.

Mazur, E. (1997). Peer instruction: A user's manual. New Jersey: Prentice Hall.

Papert, S., \& Harel, I. (1991). Situating constructionism. In S. Papert \& I. Harel (Eds.), Constructionism. Norwood, NJ: Ablex Publishing Corp.

Patry, M. (2009). Clickers in large classes: From student perceptions towards an understanding of best practices. International Journal for the Scholarship of Teaching and Learning, 3(2). Retrieved from http://www.et.kent.edu/fpdc-db/files/psych 2.pdf

Patterson, B., Kilpatrick, J., \& Woebkenberg, E. (2010). Evidence for teaching practice: The impact of clickers in a large classroom environment. Nurse Education Today, 30(7), 603-607.

Preszler, R., Dawe, A., Shuster, C., \& Shuster, M. (2007). Assessment of the effects of student response systems on student learning and attitudes over a broad range of biology course. CBE-Life Sciences Education, 6, 29-41. Retrieved from http://www.lifescied.org/cgi/reprint/6/1/29.pdf

Resta, P., \& Laferriere, T. (2007). Technology in support of collaborative learning. Educational Psychology Review, 19, 65-83.

Robinson, W. (1951). The logical structure of analytic induction. American Sociological Review, 16, 12-18.

Sandholtz, J. H., Ringstaff, C., \& Dwyer, D. C. (1994). Student engagement: Views from technology-rich classrooms. Apple Computer, Inc. Retrieved from http://www.apple.com/nl/images/pdf/acotlibrary/rpt21.pdf

Simpson, V., \& Oliver, M. (2007). Electronic voting systems for lectures then and now: A comparison of research and practice. Australasian Journal of Educational Technology, 23(2), 187-208. Retrieved from http://www.ascilite.org.au/ajet/ajet23/simpson.html

Slavin, R. E., \& Cooper, R. (1999). Improving intergroup relations: Lessons learned from cooperative learning programs. Journal of Social Issues, 55(4), 647-663.

Stagg, A., \& Lane, M. (2010). Using clickers to support information literacy skills development and instruction in first-year business students. Journal of Information Technology Education, 9, 197-215. Retrieved from http://jite.informingscience.org/documents/Vol9/JITEv9p197-215Stagg800.pdf

Tinto, V. (1997). Classrooms as communities. Journal of Higher Education, 68(6), 599-623.

Trees, A., \& Jackson, M. (2007). The learning environment in clicker classrooms: Student processes of learning and involvement in large university-level courses using student response systems. Learning, Media and Technology, 32(1), 21-40.

Van Dijk, L. A., Van Den Berg, G. C., \& Van Keulen, H. (2001). Interactive lectures in engineering education. European Journal of Engineering Education, 26, 15-28.

Vygotsky, L. (1978). Mind in society. The development of higher psychological processes. Cambridge: Harvard University Press. 
Walker, R., \& Barwell, G. (2009). Click or clique? Using educational technology to address students' anxieties about peer evaluation. International Journal for the Scholarship of Teaching and Learning, $3(1), 1-20$.

Znaniecki, F. (1934). The method of sociology. New York: Rinehart.

\section{Appendix: Data Collection Instruments}

\section{Written feedback questions}

1. Do you like learning through clickers?

2. What do you like about learning through clickers?

3. What don't you like about clickers?

4. Does the process allow you to think more about what you are learning?

5. Do you think it is the best learning method?

\section{Questions asked after second clicker intervention}

1. Did you enjoy this lesson?

2. This lesson was relevant to me as a graphic designer

3. The way questions were asked today made the discussion more interactive

4. This session helped me to establish links between theory and practice in visual communication

5. I prefer to have one clicker to myself

\section{Question asked in clicker class discussion (based on themes emerging from the written feedback questions)}

1. The clickers questions help me think more about topics

2. Clicker questions help broaden my mind

3. Clicker questions help me understand my studies better

4. Clickers force me to think

5. Clickers help me be more active in class

6. I like to see what others are thinking

7. Clickers help us learn from each other

8. Every student is active in class when we use clickers

9. I like it that clicker answers are anonymous

10. Clickers improve my interaction with my lecturers

11. Clickers help me see how experts are thinking about Graphic Design

12. I think it's important to use technology in teaching and learning

13. I enjoyed using clickers in my learning

14. I like them best because: its new, it's fun, it's simple, I can see what others are thinking, I can learn from others, it broadens my mind (ranking question) 


\section{Biographies}

Daniela Gachago has worked in the field of eLearning for more than 10 years, first for commer(a) cial companies and since 2002 in Institutions of Higher Learning. Her first experience in Africa was at the University of Botswana, where she managed the Educational Technology Unit for four years. After three years as eLearning advisor at the University of Edinburgh she started as a lecturer in the Educational Technology Unit at Fundani, the Centre for Higher Education Development at the Cape Peninsula University of Technology (CPUT), in January 2010. She holds an Honours Degree in Commerce from the Vienna University of Business and a Masters Degree in Adult Education from the University of Botswana. Her research interests are the use of emerging technologies in Higher Education and include amongst others the use of social media, personal response systems (clickers) and digital stories.

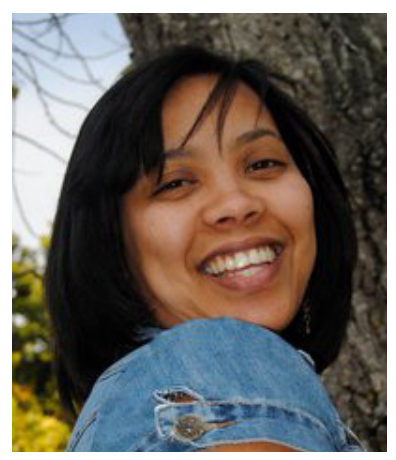

Amanda Morris is a lecturer in the Graphic Design Department at CPUT in Cape Town, South Africa. With a passion for technology and education, she endeavours to enhance both teaching and learning through the use of available technologies. She is currently completing a Masters Degree in the Faculty of Informatics and Design at CPUT.

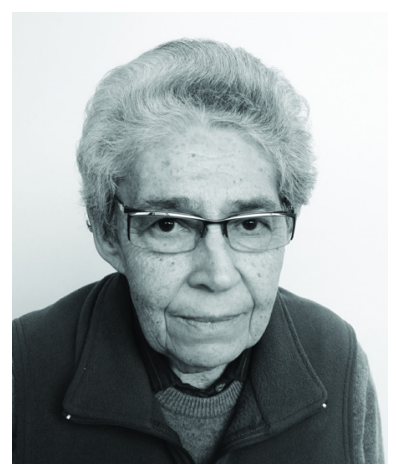

Edwine Simon is a lecturer in the Graphic Design Department at CPUT. She is also coordinating the Graphic Design Extended Curriculum Programme at the university. She holds a BAFineArt degree from the University of Cape Town and a Postgraduate Certificate in Education from the Institute of Education in London. Two of her many research interests are the potential of multilingual education in Extended Curriculum Programmes and the use of cell phone technology in Teaching and Learning. 